\title{
Use of lithium in clozapine-induced neutropenia: a case report
}

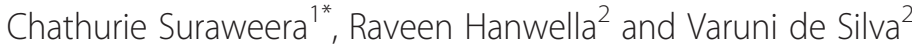

\begin{abstract}
Background: The literature describing the long-term use of lithium carbonate to reinstate reduced levels of white blood cell counts in patients treated with clozapine is scarce. We describe a case of successful recommencement of clozapine on a patient who developed risk level of neutropenia which was corrected by lithium carbonate. He was followed up for a period of one year.

Case presentation: We report a 40-year-old Sri Lankan male who developed neutropenia and low white blood cell counts following commencement of clozapine. We were successful in restarting clozapine after the addition of lithium carbonate to increase the cell counts. Clozapine was increased to $700 \mathrm{mg}$ a day with $500 \mathrm{mg}$ of lithium carbonate. The patient remains stable after one year with no further episodes of neutropenia.
\end{abstract}

Conclusion: Lithium carbonate can successfully be used to treat clozapine-induced neutropenia.

Keywords: Neutropenia, Clozapine, Lithium carbonate

\section{Background}

It is estimated that approximately $30 \%$ of patients with schizophrenia are resistant to typical and atypical antipsychotics and warrant treatment with clozapine. Clozapine should be offered to patients with treatment resistant schizophrenia (TRS) as it is the antipsychotic with most robust evidence for improving psychopathology and the quality of life [1]. However, clozapine carries a $0.9 \%$ risk of causing agranulocytosis and $2.7 \%$ risk of neutropenia [2] which could be fatal. Over $80 \%$ of such cases are seen within the first 18 weeks of treatment. Some patients who develop agranulocytosis may be genetically predisposed [3].

As a result, most clinicians are reluctant to initiate clozapine on patients. Lithium carbonate has been known to increase the white blood cell (WBC) counts in patients with leucocytopenia due to oncological causes. This has prompted clinicians to explore the possibility of using lithium carbonate in clozapine-induced neutropenia.

\section{Case presentation}

Our patient is a 40-year-old Sri Lankan male who was diagnosed with paranoid schizophrenia at the age of 22

\footnotetext{
* Correspondence: dr.chathurie@gmail.com

${ }^{1}$ University Psychological Medicine Unit, National Hospital of Sri Lanka, Colombo, Sri Lanka

Full list of author information is available at the end of the article
}

years and was resistant to adequate trials of trifluoperazine, olanzapine and risperidone. Therefore, he was started on clozapine. The patient had delusions of reference, delusional perception and commanding hallucinations which affected his day to day functioning to a great degree. He lost his job as a result of ongoing psychopathology.

His baseline white cell counts were only marginally higher than the levels recommended before initiating treatment with clozapine. The effect of clozapine and lithium carbonate on the leucocyte count of the patient is given in Table 1.

In order to initiate clozapine, patients must have a baseline WBC count of $4.0 \times 10^{3} / \mu \mathrm{l}$ and a neutrophil count of $2.5 \times 10^{3} / \mu$ l. Clozapine must be withheld if the WBC count drops below the 'red' cut-off of $3.0 \times 10^{3} / \mu \mathrm{l}$ or the neutrophil count falls below $1.5 \times 10^{3} / \mu \mathrm{l}$.

In patients with benign ethnic neutropenia, the neutrophil count before commencement of clozapine is low and persistently tends to be around the risk level. Our patient had a low baseline WBC count of $6.02 \times 10^{3} / \mu \mathrm{l}$ and a neutrophil count of $2.82 \times 10^{3} / \mu$ l before initiation of clozapine. The WBC and neutrophil counts decreased to $4.9 \times 10^{3} / \mu \mathrm{l}$ and $2.0 \times 10^{3} / \mu \mathrm{l}$ respectively, at a clozapine dose of $62.5 \mathrm{mg}$ on day 9. In such patients lack of exercise, being a non-smoker or simply having blood drawn at the wrong time of day could result in clozapine treatment 
Table 1 Effect of clozapine and lithium carbonate on white blood cell and neutrophil counts

\begin{tabular}{|c|c|c|c|c|c|c|c|c|c|c|c|c|}
\hline Day & 0 & 1 & 7 & 9 & 10 & 11 & 13 & 14 & 16 & 20 & 27 & 34 \\
\hline Total dose of clozapine $(\mathrm{mg})$ & & 12.5 & 50 & 62.5 & 0 & & & 12.5 & & 50 & 75 & 150 \\
\hline Dose of lithium carbonate $(\mathrm{mg})$ & & & & & 250 & 500 & 500 & 500 & 500 & 500 & 500 & 500 \\
\hline White cell count $\left(10^{3} / \mu \mathrm{l}\right)$ & 6.03 & & 5.8 & 4.9 & & & & 6.3 & 6.2 & 7.4 & 7.8 & 8.3 \\
\hline Neutrophil count $\left(10^{3} / \mu \mathrm{l}\right)$ & 2.82 & & 2.4 & 2.0 & & & & 2.6 & 3.4 & 3.7 & 3.7 & 3.0 \\
\hline
\end{tabular}

having to be stopped resulting in negative consequences for the patient [4]. Approximately $90 \%$ of WBC remains in storage in the bone marrow. The total lifespan of a neutrophil is 11-14 days but they die within hours after entering the circulation. Infection stimulates release and can triple the WBC count in a matter of hours. Neutrophils can either circulate freely in the bloodstream or marginate after being released from the bone marrow.

Lithium increases the neutrophil count and total WBC count both acutely and chronically [5]. This 'side-effect' of lithium has been used successfully to raise the WBC during cancer chemotherapy and in patients treated with carbamazepine. The mechanism by which lithium increases neutrophil count is not completely understood and the effect is poorly quantified. Neutrophilia does not seem to be clearly dose related although a minimum lithium serum level of $0.4 \mathrm{mmol} / \mathrm{l}$ may be required. A mean neutrophil count of $11.9 \times 10^{3} / \mu \mathrm{l}$ with a mean rise of $2.6 \times 10^{3} / \mu \mathrm{ls}$ has been reported in patients treated with lithium $[6,7]$.

We restarted clozapine at a lithium level of $0.5 \mathrm{mmol} / \mathrm{l}$ on day 14 in our patient when he had a neutrophil count of $2.6 \times 10^{3} / \mu \mathrm{l}$ and a WBC count of $6.3 \times 10^{3} / \mu \mathrm{l}$. He had a mean neutrophil count of $5.16 \times 10^{3} / \mu \mathrm{l}$ and a mean WBC count of $10.14 \times 10^{3} / \mu \mathrm{l} 6$ months after initiation of lithium. At 1 year he had a WBC count of $8.6 \times 10^{3} / \mu \mathrm{l}$ and a neutrophil count of $5.2 \times 10^{3} / \mu \mathrm{l}$. His mean lithium level at the end of 6 months was $0.55 \mathrm{mmol} / \mathrm{l}$. and 0.43 $\mathrm{mmol} / \mathrm{l}$ at the end of one year (Figure 1).

\section{Conclusion}

Our patient remains well and is currently employed. However, there are potential risks that should be borne in mind. Re-challenge with clozapine have faced with successes [8] and failures. In a retrospective review of 53 cases of clozapine re-challenge in the United Kingdom

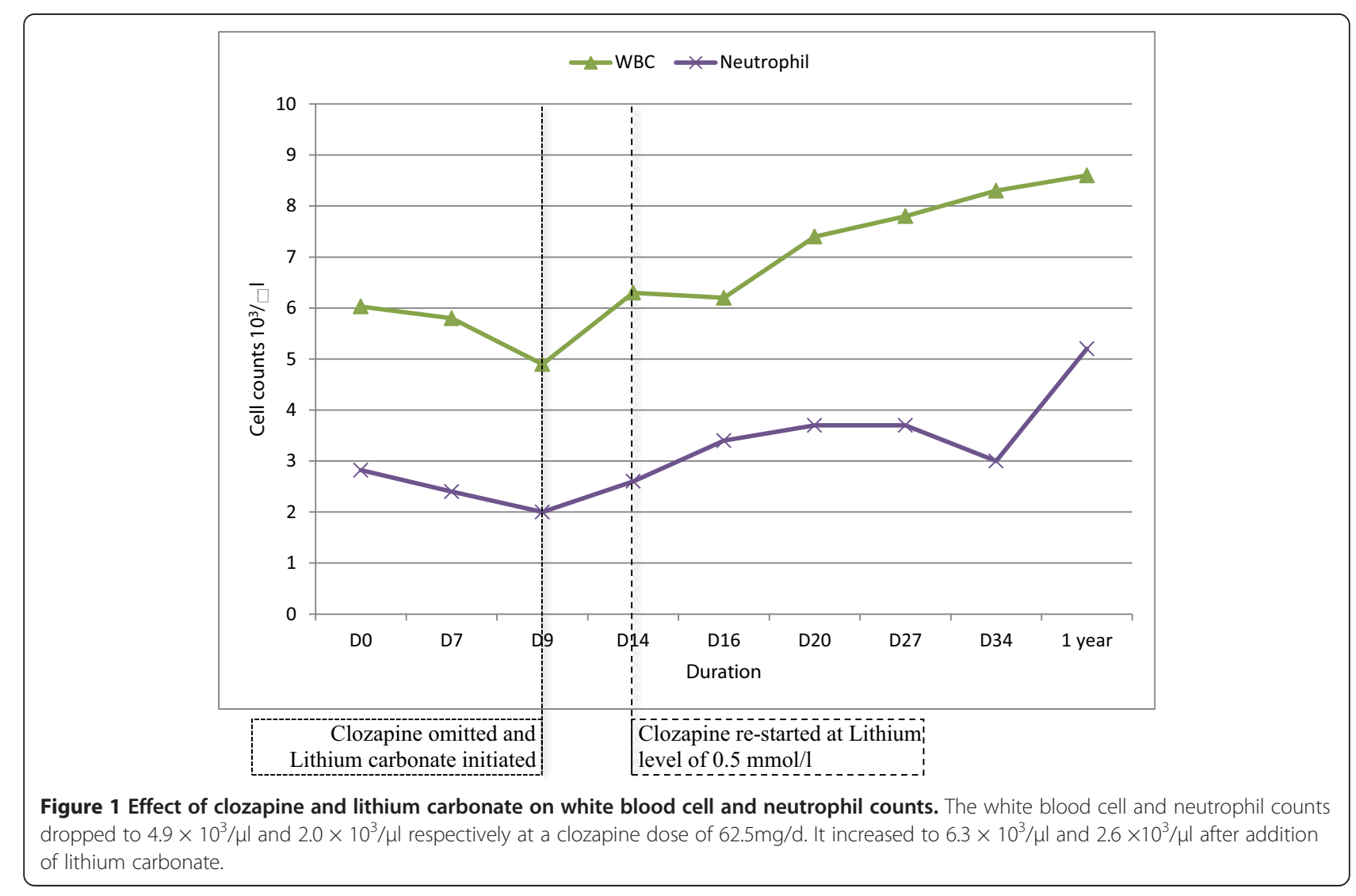


and Ireland, $62 \%$ of the patients did not develop a blood dyscrasia [9]. In $85 \%$ of the cases that developed a blood dyscrasia on re-challenge, it occurred sooner, lasted longer and was more severe than with the initial trial of clozapine. Therefore, when deciding on re-challenge with clozapine, clinicians must carefully weigh the risks and benefits. Not only the possibility of another episode of neutropenia, but toxic effects of lithium and other side effects of clozapine need particular attention.

\section{Consent}

Written informed consent was obtained from the patient for publication of this case report. A copy of the written consent is available for review by the Editor-in-Chief of this journal.

\section{Competing interests}

The authors declare that they have no competing interests.

\section{Authors' contributions}

$\mathrm{RH}$ and VS supervised CS in the management of the patient. CS, RH and VS wrote the manuscript. All authors read and approved the final manuscript.

\section{Acknowledgment}

We would like to acknowledge Dr. U T Perera for his contribution with design and editing.

\section{Author details}

'University Psychological Medicine Unit, National Hospital of Sri Lanka, Colombo, Sri Lanka. ${ }^{2}$ Department of Psychological Medicine, Faculty of Medicine, Kynsey Road, Colombo 08, Sri Lanka.

Received: 8 July 2014 Accepted: 9 September 2014

Published: 12 September 2014

\section{References}

1. Kane JM: Clinical efficacy of clozapine in treatment-refractory schizophrenia: an overview. Br J Psychiatry Suppl 1992, 17:41-45.

2. Lieberman JA: Maximizing clozapine therapy: managing side effects. J Clin Psychiatry 1998, 59(3):38-43.

3. Munro J, O'sullivan D, Andrews C, Arana A, Mortimer A, Kerwin R: Active monitoring of 12,760 clozapine recipients in the UK and Ireland. Beyond pharmacovigilance. Br J Psychiatry 1999, 175:576-580.

4. Abramson N, Melton B: Leukocytosis: basics of clinical assessment. Am Fam Physician 2000, 62:2053-2057.

5. Lapierre G, Stewart RB: Lithium carbonate and leukocytosis. Am J Hosp Pharm 1980, 37:1525-1528.

6. Blier P, Slater S, Measham T, Koch M, Wiviott G: Lithium and clozapine-induced neutropenia/agranulocytosis. Int Clin Psychopharmacol 1998, 13:137-140.

7. Paton C, Esop R: Managing clozapine-induced neutropenia with lithium. Psychiatr Bull 2005, 29:186-188.

8. Ghaznavi S, Nakic M, Rao P, Jian H, Brewer JA, Hannestad J, Bhagwagar Z: Rechallenging with clozapine following neutropenia: treatment options for refractory schizophrenia. Am J Psychiatry 2008, 165:813-818. doi:10.1176/appi.ajp.2008.07111823.

9. Atkin K, Kendall F, Gould D, Freeman H, Liberman J, O Sullivan D: Neutropenia and agranulocytosis in patients receiving clozapine in the UK and Ireland. Br J Psychiatr 1996, 169:483-488.

\section{Submit your next manuscript to BioMed Central and take full advantage of:}

- Convenient online submission

- Thorough peer review

- No space constraints or color figure charges

- Immediate publication on acceptance

- Inclusion in PubMed, CAS, Scopus and Google Scholar

- Research which is freely available for redistribution 